\title{
Increased signalling of EGFR and IGFIR, and deregulation of PTEN/PI3K/Akt pathway are related with trastuzumab resistance in HER2 breast carcinomas
}

\section{A Gallardo', E Lerma*, , D Escuin ${ }^{2}$, A Tibau ${ }^{3}$, J Muñoz', B Ojeda ${ }^{3}$, A Barnadas ${ }^{3}$, E Adrover 4 , L Sánchez-Tejada ${ }^{5}$, D Giner ${ }^{5}$, F Ortiz-Martínez ${ }^{5}$ and G Peiró ${ }^{5}$}

'Department of Pathology, Hospital de la Santa Creu i Sant Pau, Autonomous University of Barcelona, Avda. Sant Antoni Mª Claret 167, 08025, Barcelona, Spain; ${ }^{2}$ Department of Clinical Oncology, Institut de Recerca, Hospital de la Santa Creu i Sant Pau, Barcelona, Spain; ${ }^{3}$ Department of Clinical Oncology, Hospital de la Santa Creu i Sant Pau, Autonomous University of Barcelona, Barcelona, Spain; ${ }^{4}$ Department of Clinical Oncology, Hospital General Universitario, Alicante, Spain; ${ }^{5}$ Research Unit, Hospital General Universitario, Alicante, Spain

BACKGROUND: Trastuzumab resistance hampers its well-known efficacy to control HER2-positive breast cancer. The involvement of PI3KJAkt pathway in this mechanism is still not definitively confirmed.

METHODS: We selected 155 patients treated with trastuzumab after development of metastasis or as adjuvant/neoadjuvant therapy. We performed immunohistochemistry for HER2, ER/PR, epidermal growth factor I-receptor (EGFR), $\boldsymbol{\alpha}$-insulin-like growth factor I-receptor (IGFIR), phosphatase and tensin homologue (PTEN), pI I0 $\alpha$, pAkt, pBad, pmTOR, pMAPK, MUCI, Ki67, p53 and p27; mutational analysis of PIK3CA and PTEN, and PTEN promoter hypermethylation.

RESULTS: We found 46\% ER/PR-positive tumours, overexpression of EGFR (I5\%), $\alpha$-IGFIR (25\%), pI I0 $\alpha$ (I9\%), pAkt (28\%), pBad (22\%), pmTOR (23\%), pMAPK (24\%), MUCI (80\%), PTEN loss (20\%), and PTEN promoter hypermethylation (20\%). PIK3CA and PTEN mutations were detected in 17\% and $26 \%$ tumours, respectively. Patients receiving adjuvant trastuzumab with $\alpha$-IGFIR or pBad overexpressing tumours presented shorter progression-free survival (PFS) (all $P \leqslant 0.043$ ). Also, pl IO $\alpha$ and mTOR overexpression, liver and brain relapses implied poor overall survival $(O S)$ (all $P \leqslant 0.04 I$ ). In patients with metastatic disease, decreased PFS correlated with pI IO $\alpha$ expression $(P=0.024)$, whereas for OS were the presence of vascular invasion and EGFR expression $(P \leqslant 0.019$; Cox analysis). CONCLUSION: Our results support that trastuzumab resistance mechanisms are related with deregulation of PTEN/PI3K/AKt/mTOR pathway, and/or EGFR and IGFIR overexpression in a subset of HER2-positive breast carcinomas.

British Journal of Cancer (2012) I 06, 1367-1373. doi:I0.1038/bjc.2012.85 www.bjcancer.com

Published online 27 March 2012

(c) 2012 Cancer Research UK

Keywords: breast cancer; HER2; EGFR; IGFIR; PTEN/PI3K/Akt pathway; trastuzumab resistance

Breast cancer $(\mathrm{BC})$ is one of the most frequent malignancies in women (Jemal et al, 2008). HER2 overexpressing and/or gene amplified tumours represent approximately $25 \%$ of all BC, and they are associated with an aggressive phenotype, metastases, resistance to chemotherapy (CT), and poor prognosis (Slamon et al, 1987, 1989; Peiro et al, 2007; Nguyen et al, 2008). Nevertheless, the outcome has changed dramatically with the introduction of trastuzumab, a humanised monoclonal antibody that targets the HER2 extracellular domain (Murphy and Modi, 2009). It is very effective in combination with CT for the treatment of early stages (Viani et al, 2007) or metastatic BC (Pegram et al, 2004; Brufsky et al, 2005), and even as a single-agent for the later group (Vogel et al, 2002), showing in both groups of patients a substantial decrease in cancer recurrence and mortality (Slamon et al, 2001; Piccart-Gebhart et al, 2005; Joensuu et al, 2006; Untch et al, 2008). Despite its demonstrated clinical benefit, about $30-50 \%$ of patients do not respond, and those with metastasis that

*Correspondence: Dr E Lerma; E-mail: elerma@santpau.cat Received 12 December 2011; revised 10 February 2012; accepted 20 February 2012; published online 27 March 2012 achieved an initial response to trastuzumab-based regimens will develop drug resistance.

Currently, in clinical practice there are not conclusive biomarkers that allow the selection of patients who will respond to trastuzumab and the exact molecular mechanisms are still not well defined. Several growth factor receptors and signalling molecules have been proposed to be responsible for trastuzumab resistance, such as downregulation of the surface HER2 protein by endocytosis and degradation (Austin et al, 2004), p27 downregulation (Lane et al, 2001; Nahta et al, 2004), activation of insulin-like growth factor 1-receptor (IGF1R) (Lu et al, 2001; Nahta et al, 2005), interaction between HER2 and epidermal growth factor 1-receptor (EGFR) (Diermeier et al, 2005), phosphatase and tensin homologue (PTEN) loss (Nagata et al, 2004), phosphoinositide 3-kinase (PI3K)/ Akt activation (Esteva et al, 2011; Razis et al, 2011), MUC1 (Fessler et al, 2009) and MUC4 upregulation (Nagy et al, 2005), and the crosstalk with the ER signalling pathway (Slamon et al, 2001). More recently, the non-receptor tyrosine kinase c-SRC (SRC) has been suggested as a potential key modulator of trastuzumab response (Zhang et al, 2011).

Therefore, the aim of our study was to evaluate the relevance of alterations in the PI3K/Akt/mTOR and Ras/mitogen-activated 
protein kinase (MAPK) signalling pathways, given their role in cell cycle progression. We performed an extensive immunohistochemical and molecular analysis of several biological markers related with these pathways, in a series of patients with HER2-positive BC in stage I-IV, to determine their prognostic relevance, and as a result, their potential involvement in the mechanisms of response to trastuzumab.

\section{PATIENTS AND METHODS}

\section{Tumour samples and patients' follow-up}

The study was conducted according to the Declaration of Helsinki principles, with approval from the local ethics committees. A total of 155 tumour samples from HER2-positive patients were retrospectively collected from the Department of Pathology of the Hospital de la Santa Creu i Sant Pau $(n=103)$ and University General Hospital of Alicante $(n=52)$. Patients were staged according to the WHO system, and tumours were histologically graded according to Elston and Ellis method. After pathological diagnosis, patients were treated according to standard protocols. All patients received trastuzumab for the treatment of metastatic disease $(n=75)$ after failure of conventional CT with anthracyclines and/or taxanes, or for early stages either adjuvant $(n=40)$ or neoadjuvant $(n=27)$ therapy. In 13 patients the type of treatment was unknown. Median follow-up was 5.3 years (range $0.17-31$ years).

We considered response or non-resistance to trastuzumab treatment when no progression of stable disease occurred. Progression-free survival was defined as the length of time after treatment during which a patient survived with no signs of the disease, and OS as the time to the patients' death or last follow-up.

\section{Immunohistochemistry}

Tissue microarrays were prepared from paraffin-embedded tissue taken from three representative tumour areas. Sections were stained using the Envision method (Dako, Glostrup, Denmark). HER2 protein and EGFR protein determinations were performed using HercepTest and EGFR pharmaDx (Dako; Glostrup, Denmark), respectively. Antibodies, dilutions, antigen retrieval methods, and suppliers are listed in Table 1 . ER/PR and HER2 were evaluated by standard protocols. The EGFR expression was considered positive when complete membrane staining is $>10 \%$ of tumour cells. The PTEN, pAkt, pBad, p110 $\alpha$, p-mTOR, $\alpha$-IGF1R, MUC1, and pMAPK (cytoplasm) scores were calculated by multiplying the percentage of labelled cells by the staining intensity (range $0-300$ ). Loss of PTEN was considered for cutoff scores $<75$; and overexpression of p110 $\alpha$, MUC1, pMAPK, p27 and pAkt were considered for scores $\geqslant 150$. Positive $\alpha$-IGF1R and mTOR were considered for scores $\geqslant 220$ and $\geqslant 30$, respectively. The percentage of stained nuclei was evaluated independently of the intensity for Ki67 (cutoff 20\%) and p53 (cutoff $10 \%$ ). Consensus between three pathologists (AG, EL, and GP) was done for the immunohistochemical results.

\section{Mutational analysis of PIK3CA}

Genomic DNA was extracted from frozen tumour or paraffinembedded tissues and mutational analysis of PIK3CA was performed by PCR and direct sequencing using primers for exons 9 and 20 as previously described (Samuels et al, 2004).

\section{Phosphatase and tensin homologue mutation and promoter hypermethylation}

Mutational analysis was performed using previously reported PCR conditions and primers for exons 3,5, 7, and 8 (Bussaglia et al, 2000). Methylation-specific PCR was used to assay CpG island methylation status of the PTEN promoter gene using the Methylamp One-Step DNA Modification kit (Epigentek, Brooklyn, NY, USA). Three primers sets were used for the PCR as previously reported (Soria et al, 2002).

\section{In situ hybridisation analysis}

HER2 gene status was confirmed by fluorescence in situ hybridisation (Dako pharmaDx) or chromogenic in situ hybridisation (Spot light; Zymed, Paisley, UK) in equivocal cases.

\section{Statistical analyses}

They were performed with the SPSS/win 17. 0 statistical software package (SPSS, Chicago, IL, USA). Qualitative variables were compared with the X2/Fisher tests. A receiver operating characteristic curve and area under the curve were generated to determine a cutoff value of the expression of several biomarkers and the potential clinical utility to predict prognosis. The KaplanMeier method and the Cox regression model were used to estimate survival. $P$-values $<0.05$ were considered statistically significant.

\section{RESULTS}

\section{Clinicopathological data}

The clinicopathological data is summarised in Table 2. Patients were classified into two groups: group A $(n=75)$ included patients where trastuzumab was included for treatment of metastatic disease and group B ( $n=67$ patients) those with trastuzumab in the adjuvant/neoadjuvant setting. Median age was 55 years (range 31 - 92 years) and median tumour size was $2.5 \mathrm{~cm}$ (range $1-20 \mathrm{~cm}$ ). Histological grade 1 was seen in $7(5 \%)$ cases, grade 2 in $50(32 \%)$,

Table I Panel of antibodies for the immunohistochemical analysis

\begin{tabular}{|c|c|c|c|c|}
\hline Antibody & Clone & Dilution & Supplier & Pretreatment \\
\hline ER & $6 \mathrm{FII}$ & $1: 40$ & Novocastra (Newcastle, UK) & Citrate buffer $\mathrm{pH}$ 6. Autoclave, $8 \mathrm{~min}$ \\
\hline PR & 16 & $1: 200$ & Novocastra (Newcastle, UK) & Citrate buffer $\mathrm{pH}$ 6. Autoclave, $8 \mathrm{~min}$ \\
\hline$\alpha|G F| R$ & $24-31$ & $1: 200$ & Neomarkers (Freemont, CA, USA) & Citrate buffer $\mathrm{pH}$ 6. Autoclave, $8 \mathrm{~min}$ \\
\hline PTEN & $6 \mathrm{H} 2.1$ & $\mid: 50$ & Cascade Biosciences (Winchester, MA, USA) & Citrate buffer $\mathrm{pH}$ 6. Autoclave, $40 \mathrm{~min}$ \\
\hline$p \mid 10 \alpha$ & Rabbit polyclonal & $1: 25$ & Cell Signaling (Beverly, MA, USA) & EDTA buffer $\mathrm{pH}$ 8. Autoclave, $8 \mathrm{~min}$ \\
\hline pAkt & Rabbit monoclonal & $1: 50$ & Cell Signaling (Beverly, MA, USA) & EDTA buffer $\mathrm{pH}$ 8. Autoclave, $8 \mathrm{~min}$ \\
\hline pBAD & Sc-12969-R & $1: 40$ & Santa Cruz (Santa Cruz, CA, USA) & EDTA buffer $\mathrm{pH}$ 8. Autoclave, $8 \mathrm{~min}$ \\
\hline mTOR & Rabbit polyclonal & $1: 50$ & Cell Signaling (Beverly, MA, USA) & EDTA buffer $\mathrm{pH}$ 8. Autoclave, $8 \mathrm{~min}$ \\
\hline $\mathrm{MUCl}$ & $\mathrm{BC}-2$ & $1: 40$ & Signet (Dedham, MA, USA) & Citrate buffer $\mathrm{pH}$ 6. Autoclave, $8 \mathrm{~min}$ \\
\hline PMAPK & Rabbit IgG monoclonal & $1: 100$ & Cell Signaling (Beverly, MA, USA) & EDTA buffer $\mathrm{pH}$ 8. Autoclave, $8 \mathrm{~min}$ \\
\hline Ki67 & MIB-I & Prediluted & Dako (Carpinteria, CA, USA) & Citrate buffer $\mathrm{pH}$ 6. Autoclave, $8 \mathrm{~min}$ \\
\hline p53 & DO-7 & Prediluted & Dako (Carpinteria, CA, USA) & Citrate buffer $\mathrm{pH}$ 6. Autoclave, $8 \mathrm{~min}$ \\
\hline p27 & SX53G8 & $1: 50$ & Dako (Carpinteria, CA, USA) & EDTA buffer $\mathrm{pH}$ 8. Autoclave, $8 \mathrm{~min}$ \\
\hline
\end{tabular}


Table 2 Summary of the main clinicopathological data

\begin{tabular}{|c|c|c|c|}
\hline & $\begin{array}{l}\text { All cases } \\
(n=155)\end{array}$ & $\begin{array}{l}\text { Trastuzumab in } \\
\text { the metastatic } \\
\text { disease }(n=75)\end{array}$ & $\begin{array}{l}\text { Trastuzumab in } \\
\text { the first-line } \\
\text { treatment } \\
(n=67)\end{array}$ \\
\hline $\begin{array}{l}\text { Age } \\
\text { (median and range) }\end{array}$ & $\begin{array}{c}55 \text { years } \\
\text { (31-92 years) }\end{array}$ & $\begin{array}{c}59 \text { years } \\
\text { (31-92 years) }\end{array}$ & $\begin{array}{c}54 \text { years } \\
\text { (33-88 years) }\end{array}$ \\
\hline $\begin{array}{l}\text { Tumour size } \\
\text { (median and range) }\end{array}$ & $\begin{array}{l}2.5 \mathrm{~cm} \\
(\mathrm{I}-20 \mathrm{~cm})\end{array}$ & $\begin{array}{c}2.8 \mathrm{~cm} \\
(1-11 \mathrm{~cm})\end{array}$ & $\begin{array}{c}2.4 \mathrm{~cm} \\
(4-20 \mathrm{~cm})\end{array}$ \\
\hline \multicolumn{4}{|l|}{$B C$ subgroups } \\
\hline HER2 $+/ H R+$ & 67 & 35 & 29 \\
\hline $\mathrm{HER} 2+/ \mathrm{HR}-$ & 78 & 33 & 37 \\
\hline Unknown & 10 & 7 & 1 \\
\hline \multicolumn{4}{|l|}{ Lymph node status } \\
\hline Negative & 46 & 20 & 24 \\
\hline Positive & 89 & 47 & 36 \\
\hline Unknown & 20 & 8 & 7 \\
\hline \multicolumn{4}{|l|}{ Stage } \\
\hline IA & 17 & 8 & 8 \\
\hline$\| A$ & 29 & 10 & 17 \\
\hline$\| \mathrm{B}$ & 15 & 8 & 6 \\
\hline$\| I \mathrm{~B}$ & 42 & 22 & 17 \\
\hline$\| \mathrm{A}$ & 18 & 13 & 5 \\
\hline $\mathrm{IIC}$ & 12 & 9 & 3 \\
\hline IV & 13 & 3 & 7 \\
\hline Unknown & 9 & 2 & 4 \\
\hline \multicolumn{4}{|l|}{ Histological grade } \\
\hline | & 7 & 1 & 4 \\
\hline 2 & 50 & 24 & 23 \\
\hline 3 & 98 & 50 & 40 \\
\hline \multicolumn{4}{|l|}{ DCIS } \\
\hline$<25 \%$ & 25 & 12 & 12 \\
\hline$>25 \%$ & 22 & 9 & 13 \\
\hline \multicolumn{4}{|l|}{ Follow-up } \\
\hline NED & 56 & 5 & 50 \\
\hline AWD & 31 & 21 & 10 \\
\hline DOD & 57 & 49 & 7 \\
\hline LFU & | | & 0 & 0 \\
\hline
\end{tabular}

Abbreviations: $A W D=$ alive with disease; $B C=$ breast carcinoma; $D C I S=$ ductal carcinoma in situ; DOD = dead of the disease; $H R=$ hormonal receptors; $L F U=$ lost of follow-up; NED = no evidence of disease

and grade 3 in $98(63 \%)$ tumours. Vascular invasion was found in $32 \%$ (47 of 145) cases. Axillary lymph node dissection was performed in 135 patients, being positive in 89 cases (66\%). Tumour stage was IA in $17(11 \%)$ patients, IIA in $29(18.8 \%)$, IIB in $15(9.7 \%)$, IIIA in $42(27 \%)$, IIIB in $18(11.6 \%)$, IIIC in $12(7.7 \%)$, IV in $13(8.4 \%)$, and was unknown in $9(5.8 \%)$ patients. A total of 11 patients were lost in the follow-up, and among those remaining, $56(39 \%)$ were alive with no evidence of disease, $31(21.5 \%)$ alive with disease, and 57 (39.5\%) died of the disease (DOD).

\section{Tumour molecular features}

Table 3 includes the relationship between clinicopathological and molecular data for all patients. Examples of relevant immunohistochemical images are shown in Figure 1.

Hormonal receptors (HR) The HR (either ER or PR) were positive in $46 \%(67 / 145)$ of the tumours, and they were associated with ductal formation $(P=0.024)$ and histological grade $1(P=0.048)$.

Growth factor receptors Increased EGFR expression was found in $15 \%$ tumours (21/141) and correlated with high mitotic index $(P=0.013)$ and negative HR $(P<0.000)$, and there was a trend towards higher tumour grade $(P=0.061)$.
Table 3 Statistical correlations between clinicopathological, immunohistochemical and molecular data for all tumours

\begin{tabular}{|c|c|c|c|c|c|c|}
\hline & $\begin{array}{c}\text { Histological } \\
\text { grade }\end{array}$ & $\begin{array}{l}\text { Ductal } \\
\text { form }\end{array}$ & $\begin{array}{c}\text { Nuclear } \\
\text { grade }\end{array}$ & Mitosis & $\begin{array}{l}\text { Lymph } \\
\text { node + }\end{array}$ & $\begin{array}{l}\text { Vascular } \\
\text { invasion }\end{array}$ \\
\hline $\mathrm{HR}-$ & $0.080^{\mathrm{a}}$ & $0.024^{\mathrm{a}}$ & NS & $0.091^{\mathrm{a}}$ & NS & NS \\
\hline EGFR+ & 0.061 & 0.083 & NS & 0.013 & 0.088 & NS \\
\hline$\alpha|G F| R+$ & 0.001 & NS & 0.07 & 0.004 & NS & 0.005 \\
\hline PTEN loss & 0.065 & NS & NS & NS & NS & 0.047 \\
\hline PIK3CA mut & NS & NS & 0.043 & NS & NS & NS \\
\hline pAkt+ & NS & NS & NS & NS & NS & NS \\
\hline pBad+ & 0.001 & NS & 0.008 & 0.002 & NS & 0.006 \\
\hline mTOR+ & NS & NS & 0.034 & NS & 0.12 & NS \\
\hline MAPK+ & $0.029^{a}$ & NS & NS & NS & NS & NS \\
\hline Ki67 > 20\% & 0.087 & NS & NS & 0.021 & NS & 0.082 \\
\hline$p 53>10 \%$ & NS & NS & 0.009 & 0.076 & NS & NS \\
\hline p27+(nuclear) & NS & NS & NS & NS & NS & NS \\
\hline
\end{tabular}

Abbreviations: EGFR = epidermal growth factor I-receptor: HR= hormonal receptors; $I G F I R=$ insulin-like growth factor I-receptor; $M A P K=$ mitogen-activated protein kinase; $\mathrm{NS}=$ non-significant; $\mathrm{PTEN}=$ phosphatase and tensin homologue. ${ }^{\text {a }}$ Inverse relationship.
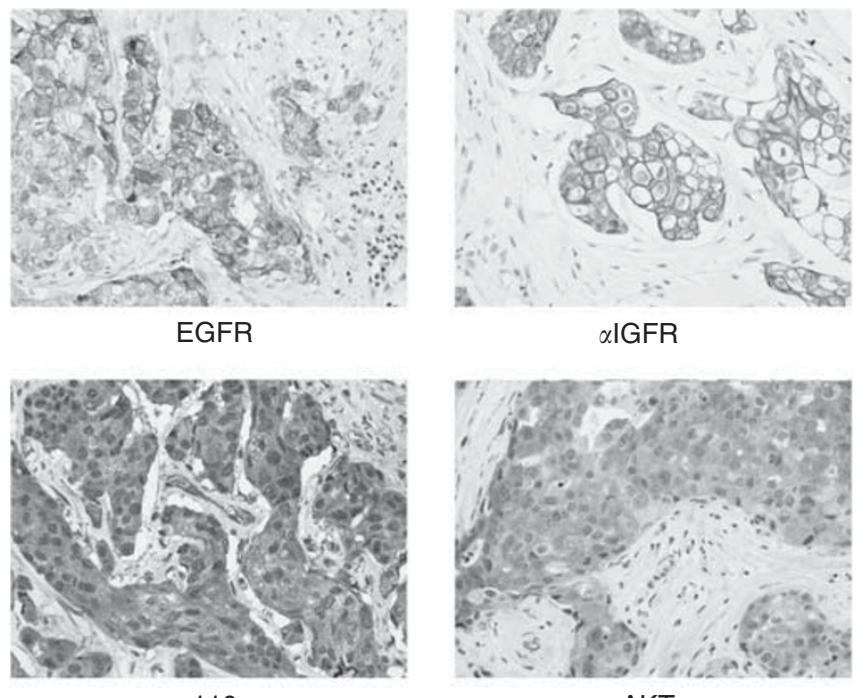

p110a

pAKT

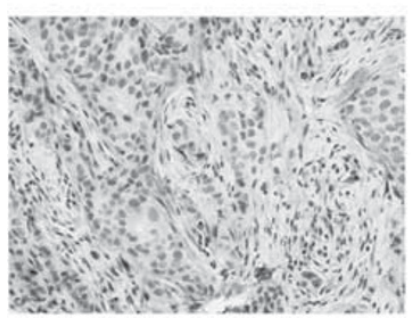

PTEN

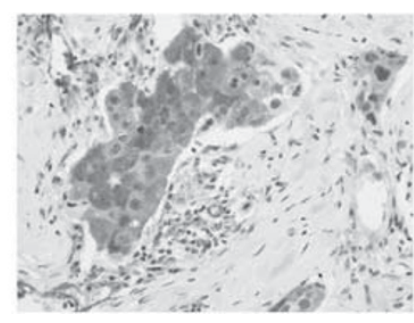

pBAD

Figure I Immunohistochemical expression of EGFR, $\alpha|G F R, p| \mid 0 a$, pAKT, pBad, and loss of PTEN in HER2-positive breast carcinomas.

Staining of $\alpha$-IGF1R was strong and diffuse (overexpression) in $25 \%$ tumours $(34 / 138)$, in association with high grade $(P=0.001)$, high mitotic index $(P=0.004)$, and vascular invasion $(P=0.005)$.

Biomarkers associated with the PI3K/Akt/mTOR and MAPK signalling pathways Phosphatase and tensin homologue loss was found in $20 \%$ of the tumours (30/149), PTEN promoter hypermethylation in $20 \%(22 / 110)$ and mutations in $26 \%(8 / 30)$. Phosphatase and tensin homologue loss was associated with vascular invasion $(P=0.047)$ and higher grades $(P=0.065)$, but 
Table 4 Statistical significance according to metastatic site for all patients. (Note: EGFR, p53, p27, and MAPK expression levels were unrelated with metastases)

\begin{tabular}{|c|c|c|c|c|c|c|c|}
\hline & Liver & Bone & CNS & Skin and soft tissue & Lung & Pleura & Lymph nodes \\
\hline $\mathrm{HR}+$ & NS & 0.008 & NS & $0.069^{\mathrm{a}}$ & NS & NS & NS \\
\hline ER+ & NS & 0.004 & NS & 0.082 & NS & NS & NS \\
\hline $\mathrm{PR}+$ & NS & 0.044 & NS & 0.090 & NS & NS & NS \\
\hline \multicolumn{8}{|l|}{ PTEN } \\
\hline - Loss expr & NS & NS & 0.058 & NS & NS & NS & NS \\
\hline \multicolumn{8}{|l|}{ PIK3CA } \\
\hline - Mutat & NS & NS & NS & NS & 0.087 & NS & NS \\
\hline pAkt+ & NS & 0.085 & NS & NS & NS & NS & NS \\
\hline mTOR+ & 0.069 & NS & NS & NS & NS & NS & NS \\
\hline Ki67 > 20\% & 0.011 & 0.011 & 0.037 & NS & NS & 0.049 & 0.096 \\
\hline
\end{tabular}

Abbreviations: $C N S=$ central nervous system; $E R=$ oestrogen receptor; $H R=$ hormonal receptors; $I H C=$ immunohistochemistry; mutat $=$ mutations; $N S=$ non-significant;

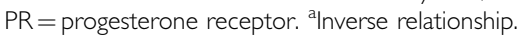

neither association with PTEN mutation nor hypermethylation was found.

p110 $\alpha$ (PI3K catalytic subunit) overexpression was present in $19 \%$ of the tumours (24/125), and PIK3CA somatic missense mutations were identified in $17 \%(24 / 142)$ : in exon 20 (nucleotide A3140G, amino acid H1047R) in $15 \%$ of the tumours (21/142), whereas mutations in the helical domain of exon 9 (nucleotide G1635C, amino acid E545D) were detected in only 6\% (3/50). Interestingly, mutations were present more frequently in tumours with EGFR expression $(33 \% ; P=0.016)$ and higher nuclear grade $(P=0.043)$, but there was no correlation with $\mathrm{p} 110 \alpha$ protein expression.

pAkt overexpression was found in $28 \%$ of the tumours $(40 / 143)$ and phosphorylated (inactive) Bad in 22\% (30/139) in association with high nuclear $(P=0.008)$ and histological grades $(P=0.001)$, elevated mitotic index $(P=0.002)$, and vascular invasion $(P=0.006)$. mTOR overexpression was detected in $23 \%(33 / 142)$ of the tumours, predominantly with high nuclear grade tumours $(P=0.034)$, and in association with $\alpha$-IGF1R $(47 \% ; P<0.000)$, $\mathrm{p} 110 \alpha(64 \% ; P=0.028)$ and pBad $(65 \% ; P=0.027)$.

Strong pMAPK expression in $24 \%(22 / 93)$ of the tumours predominated in those of low grade $(P=0.029)$; MUC1 was overexpressed in $80 \%$ of the analysed tumours (77/96) but without significant association with clinicopathological features.

Cell proliferation and apoptosis markers Ki67 $>20 \%$ was seen in $51 \%$ of the tumours $(73 / 144)$, related with high mitotic index $(P=0.021)$. p53 overexpression was found in $30 \%$ of the tumours $(42 / 139)$ associated with HR-negative status $(P=0.022)$ and high nuclear grade $(P=0.009)$. Only $17 \%(16 / 94)$ of the cases showed p27 nuclear expression but unrelated with any clinical-pathological factors.

\section{Relationship between biomarkers and recurrence}

In all, $61 \%$ of the patients developed distant metastases, which were located in the liver (35\%), bone (35\%), lung (27\%), lymph nodes $(21 \%)$, pleura $(18 \%)$, central nervous system (CNS; $16 \%$ ), and skin (14\%). Patients with HR-positive tumours presented more frequently bone metastases $(P=0.008)$ compared with those with HR-negative status. In contrast, tumours with $\alpha$-IGF1R overexpression rarely metastasised to the liver $(P=0.009)$, lung $(P=0.002)$, bone $(P=0.031)$ or lymph nodes $(P=0.007)$. Patients with $110 \alpha$-positive tumours developed more frequently CNS metastases $(P=0.029)$. The remaining proteins studied here
Table 5 Multivariate analysis of histological and biological factors for patients with trastuzumab treatment in the metastatic disease (group A) (Cox model)

\begin{tabular}{lcccc}
\hline Variables & B & Hazard ratio & $\mathbf{9 5 \%} \mathbf{C l}$ & P-value \\
\hline $\begin{array}{l}\text { Disease-free survival } \\
\text { CNS metastasis }\end{array}$ & 1.128 & 3.59 & $1.23-10.51$ & 0.020 \\
PlI0 $\alpha$ & 1.269 & 2.75 & $1.14-6.49$ & 0.024 \\
& & & & \\
Overall survival & & & & \\
$\quad$ Vascular invasion & 1.17 & 3.36 & $1.22-8.94$ & 0.015 \\
CNS metastasis & 1.406 & 4.22 & $1.44-12.38$ & 0.009 \\
EGFR & 1.630 & 5.25 & $1.32-20.92$ & 0.019 \\
\hline
\end{tabular}

Abbreviations: $C N S=$ central nervous system; EGFR = epidermal growth factor I-receptor.

showed a trend or were not associated with any specific site of dissemination (see Table 4).

\section{Survival analyses}

In order to perform the survival analysis in similar patients groups, we excluded those that received neoadjuvant CT or stage IV. Therefore, 51 patients remained in group A and 38 patients in group B. Supplementary Figures 1 and 2 include the Kaplan - Meier curves for both groups. Table 5 shows the results of the multivariate analysis.

Metastatic BC (group A) A total of 47 patients $(92 \%, 47 / 51)$ had tumour recurrence with a median PFS of 2.6 years (range 1.01 to 11.64 years) and $65 \%(33 / 51)$ of the patients DOD with a median OS of 7.5 years (range 0.17 to 21 years).

Univariate analysis (Kaplan-Meier; log rank test) showed that shorter PFS was associated with vascular invasion $(P=0.042)$, mutated PTEN $(P=0.045)$, EGFR $(P=0.026), \mathrm{p} 110 \alpha(P=0.004)$, pAkt overexpression $(P=0.016)$, and CNS metastases $(P=0.002)$. Poor OS correlated with positive lymph node status $(P=0.013)$, EGFR $(P=0.006), \quad$ p110 $\alpha \quad(P=0.079)$, pAkt overexpression $(P=0.042)$, tumour stage $(P=0.003)$, and tumour relapses in the liver $(P=0.059)$ or in CNS $(P=0.005)$.

Multivariate analyses for PFS revealed that only the presence of metastases to the CNS $(P=0.020$, HR 3.59, CI $1.23-10.51)$ and p110 $\alpha$ overexpression $(P=0.024$, HR 2.75 , CI $1.14-6.49)$ emerged 
as significant predictors of relapse. Worse OS was seen for vascular invasion $(P=0.015$, HR 3.36; CI 1.22-8.94), EGFR expression $(P=0.019$, HR 5.25; CI $1.32-20.92)$, and metastases to the CNS $(P=0.009$, HR 4.22; CI 1.44-12.38) (Cox regression model).

Early-stage BC (group B) Only 11\% (4/38) of the patients had tumour recurrence and $5 \%$ died from the tumour. These events might be, however, related to the short follow-up of the majority of the patients (median 2.82 years). Median PFS was 2.81 years (range $1.00-8.28$ years) and for OS was 2.82 years (range $1.00-8.42$ years).

Shorter PFS was associated with $\alpha$-IGF1R $(P=0.028)$, pBad overexpression $(P=0.003)$, and tumour recurrence in the liver $(P=0.003)$ or the bone $(P=0.001)$. Poor OS correlated with high tumour grade $(P<0.000)$, overexpression of p110 $(P=0.041)$ and mTOR (77 vs $100 \%$ in negative cases; $P=0.006$ ), and tumour recurrence in the liver $(P=0.009)$ and CNS $(P=0.011)$ (KaplanMeier; log rank test). Nevertheless, the multivariate analysis (Cox regression) showed that these results did not reach any statistically significance, probably due to the small number of events in this group.

\section{DISCUSSION}

In the current study, we performed an extensive immunohistochemical and molecular analysis of biological markers related with the PI3K/Akt/mTOR and Ras/MAPK signalling pathways in a series of HER2-positive BC patients who received trastuzumab for metastatic disease or as first-line therapy in earlier stages. We found that patients with primary tumours showing alterations in EGFR and PTEN/PI3K/Akt had shorter PFS and OS despite trastuzumab treatment when given at advanced stage (metastatic disease), supporting their role in the mechanisms of response. Our results in the group of patients in earlier stages who received trastuzumab as adjuvant/neoadjuvant therapy demonstrated that those having tumours with IGF1R overexpression and inactive Bad had shorter PFS. Poorer OS was seen in patients who developed metastatic disease especially in the brain and liver, and with p110 $\alpha$ and mTOR overexpressing tumours. Nevertheless, none of the factors had an independent prognostic value, probably related with the small number of events and short follow-up of this group.

PI3K/Akt signalling is one of the most critical cancer-promoting pathways through upregulation of growth factor receptors (EGFR, IGF1R, HER2, etc) or PTEN inactivation (Lu et al, 1999) and recently considered a major determinant of trastuzumab resistance (Nagata et al, 2004; Berns et al, 2007; Esteva et al, 2011; Razis et al, 2011). HER2 and EGFR coexpression has a considerable inhibitory effect on this drug (Diermeier et al, 2005) and are associated with poor prognostic factors such as high grade, negative HR status, and vascular invasion (Abd El-Rehim et al, 2004). In agreement with these findings, we found coexpression in $15 \%$, which in turn was related with PIK3CA mutations. Insulin-like growth factor 1-receptor has an important role in growth and invasiveness of $\mathrm{BC}$ (Peiro et al, 2009, 2011) and recently has also been involved in trastuzumab resistance (Lu et al, 2001; Nahta et al, 2005; Harris et al, 2007). In fact, we found IGF1R overexpression in $25 \%$ of the tumours, especially in those of early stage patients who developed recurrences. Of note, there is considerable evidence that both IGF1R and EGFR crosstalk in BC cells and their coactivation occurs in approximately $25 \%$ of BC, related with poor outcome (Harris et al, 2001, 2007; Lu et al, 2001; Abd El-Rehim et al, 2004). Therefore, it would be expected that those patients would be more likely to be resistant to trastuzumab.

PTEN encodes a protein that inhibits activation of the PI3K/Akt/ mTOR signalling pathway (Panigrahi et al, 2004). The PTEN inactivation may be related with gene mutations $(<5 \%$ of sporadic BC) (Vanhaesebroeck and Alessi, 2000) or promoter hypermethylation $(20 \%)$ (Saal et al, 2005), resulting in PTEN loss that occurs in about half of the tumours (Nagata et al, 2004; Lerma et al, 2008;
Esteva et al, 2011; Razis et al, 2011). Prior experimental studies with SKBR3 and BT474 BC cells and in breast tumour xenografts demonstrated that PTEN reduction confers resistance to trastuzumab's antitumour function, and this data was subsequently confirmed in a group of patients (Nagata et al, 2004). In the current study, PTEN loss or promoter hypermethylation were observed both in $20 \%$ of the tumours but without association with patient's survival, despite their correlation with other adverse clinicopathological data, such as vascular invasion and lymph node metastases. Nevertheless, tumours with PTEN mutations $(26 \%)$ recurred more frequently in patients with metastatic disease, supporting its contribution to trastuzumab resistance.

The PI3K/Akt pathway activation blocks apoptosis and promotes cellular proliferation through interaction with different downstream effectors (Stemke-Hale et al, 2008; Di Cosimo and Baselga, 2008; Nahta and O'Regan, 2011; Margariti et al, 2011). PIK3CA activating mutations, clustered in exons 9 (helical domain) and 20 (kinase domain) have been reported in $18-40 \%$ BC, occasionally associated with HER2 phenotype (Stemke-Hale et al, 2008) and tumour recurrence (Razis et al, 2011). We found PIK3CA mutations in $17 \%$ of the tumours, unrelated with trastuzumab clinical benefit. In contrast, p110 $\alpha$ overexpression (19\%) had an independent poor prognostic value for progression in patients with advanced stage. Moreover, active Akt in $28 \%$ of our tumours, correlated with recurrence and poor patients' survival, supporting that activation of this pathway contributes to tumour growth and therefore to trastuzumab resistance. Further, inactive Bad seen in $22 \%$ of the tumours in association with adverse prognostic parameters, such as high tumour grade, high mitotic index and vascular invasion, predicted shorter survival as a result of non-response, in early stage patients. In partial agreement with our data, Esteva et al (2011), in a previous series of 137 metastatic BC, found that PI3K pathway activation (defined as PTEN loss and/or PIK3CA mutation) significantly contributed to worse response to trastuzumab and shorter OS. Moreover, pAkt and PTEN status combination showed more power than PTEN loss alone.

mTOR is a key regulator of multiple cell stimuli integrating growth factor and cytokine signals. In vitro studies and recent clinical data have confirmed a relationship between mTOR and HER2 (Morrow et al, 2011) as well as its role in trastuzumab resistance (Nahta and O'Regan, 2011). In our series, 23\% of predominantly pleomorphic tumours contained increased mTOR, and these patients had lymph-node metastasis. Of note, we found that mTOR modulation by PI3K/Akt-dependent mechanisms reflected by its positive correlation with $\mathrm{p} 110 \alpha$ and $\mathrm{Bad}$ is influenced by IGF1R. Further, supporting its involvement in the mechanisms of trastuzumab responsiveness, all our patients from the group B and negative mTOR tumours were alive at the last follow-up compared with only $77 \%$ for those with positive tumours. This is of interest as preclinical models have shown that dual inhibition of both IGF1R - with either monoclonal antibodies or tyrosine kinase inhibitors - and mTOR results in a superior antiproliferative effect over each single strategy, and this combination is now under evaluation in phase I/II trials in patients with BC (Di Cosimo and Baselga, 2008). Nevertheless, the mechanisms of how mTOR inhibitors reverse resistance to trastuzumab still remain unexplained (Nahta and O'Regan, 2011).

The antiproliferative effect of trastuzumab has been also linked to p27, cyclin E-CDK complex or IGF1R interaction in clinical and in vitro studies (Lane et al, 2001; Lu et al, 2004; Nahta et al, 2004). Nevertheless, we were not able to demonstrate any significant correlation between p27, biomarkers or clinicopathological data.

MAPK/ERK pathway stimulation has been related with the oncogenic potential of HER2 and trastuzumab resistance (Berns et al, 2007; Yao et al, 2009). Nevertheless, recent data support the assertion that trastuzumab has less effect on this cell cycle kinetics pathway (Dave et al, 2011), and therefore, not relevant in the development of resistance, in line with our study. 
Using a full-length MUC1 antibody, we found expression in $80 \%$ of the tumours, with neither correlation with prognostic indicators nor survival. Recent studies have now shown it is not related to tumour growth but it is present in newly differentiated stem cells. However, the cleaved form of the MUC1 protein (MUC1*) has growth factor receptor-like activity on tumour cells and is detected in populations of pluripotent stem cells (Hikita et al, 2008; Mahanta et al, 2008). Fessler et al (2009) showed upregulation of $\mathrm{MUC1}^{*}$ in HER2-amplified/trastuzumab-resistant BC cells. Further treatment with $\mathrm{MUC1}^{*}$ antagonists in addition to trastuzumab reversed that resistance (Fessler et al, 2009). Therefore, further studies on $\mathrm{MUC1}^{\star}$ are needed to confirm the previous data in clinical series. Finally, p53 and Ki67, two well-known prognostic factors (Jansen et al, 1998; Yamashita et al, 2004) that were increased in a significant number of tumours and associated with poor pathological features, lacked significance with respect to survival.

The results reported here mostly agree with those reported in the literature derived from experimental and clinical series. Nevertheless, our study was not conducted in patients included in a clinical trial, and a control (no-trastuzumab) group was not included. Therefore, the additional influence of CT and poor prognostic factors to the markers associated with trastuzumab resistance cannot be stated with certainty.

In summary, we found in about one-forth of HER2 tumours at least one molecular alteration in the PI3K pathway and/or its upstream or downstream effectors. Our data support the complex interactions between EGFR, IGF1R, and the PTEN/PI3K/Akt/Bad and mTOR signalling pathway, which in turn are potentially related with the mechanisms of trastuzumab response. Nevertheless, some of these biomarkers need to be further validated in larger series and introduced into the clinical practice to carefully select patients on the basis of tumour molecular alterations. This is of relevance as novel combinations for targeting simultaneously several factors might suggest another strategy to overcome trastuzumab resistance and enhance response rates.

\section{ACKNOWLEDGEMENTS}

We thank Patricia Picó, María D Durán, and Daniel Fernandez for their technical assistance, and Doreen A Denecker for the preparation of the manuscript. Sources of support: This work was supported in part by grants from Fondo de Investigaciones Sanitarias (FIS PI06/0709 and PI06/1495), Instituto Carlos III RTICCCFIS RD06/0020/0015, Pfizer Laboratories, Mutua Madrileña Foundation (448/2008), and ROCHE Diagnostics-Sociedad Española de Anatomía Patológica (SEAP).

\section{CONFLICT OF INTEREST}

The authors declare no conflict of interest.

Supplementary Information accompanies the paper on British Journal of Cancer website (http://www.nature.com/bjc)

\section{REFERENCES}

Abd El-Rehim DM, Pinder SE, Paish CE, Bell JA, Rampaul RS, Blamey RW, Robertson JF, Nicholson RI, Ellis IO (2004) Expression and coexpression of the members of the epidermal growth factor receptor (EGFR) family in invasive breast carcinoma. Br J Cancer 91: 1532 - 1542

Austin CD, De Maziere AM, Pisacane PI, van Dijk SM, Eigenbrot C, Sliwkowski MX, Klumperman J, Scheller RH (2004) Endocytosis and sorting of ErbB2 and the site of action of cancer therapeutics trastuzumab and geldanamycin. Mol Biol Cell 15: 5268-5282

Berns K, Horlings HM, Hennessy BT, Madiredjo M, Hijmans EM, Beelen K, Linn SC, Gonzalez-Angulo AM, Stemke-Hale K, Hauptmann M, Beijersbergen RL, Mills GB, van de Vijver MJ, Bernards R (2007) A functional genetic approach identifies the PI3K pathway as a major determinant of trastuzumab resistance in breast cancer. Cancer Cell 12: 395-402

Brufsky A, Lembersky B, Schiffman K, Lieberman G, Paton VE (2005) Hormone receptor status does not affect the clinical benefit of trastuzumab therapy for patients with metastatic breast cancer. Clin Breast Cancer 6: $247-252$

Bussaglia E, del Rio E, Matias-Guiu X, Prat J (2000) PTEN mutations in endometrial carcinomas: a molecular and clinicopathologic analysis of 38 cases. Hum Pathol 31: 312-317

Dave B, Migliaccio I, Gutierrez MC, Wu MF, Chamness GC, Wong H, Narasanna A, Chakrabarty A, Hilsenbeck SG, Huang J, Rimawi M, Schiff R, Arteaga C, Osborne CK, Chang JC (2011) Loss of phosphatase and tensin homolog or phosphoinositol-3 kinase activation and response to trastuzumab or lapatinib in human epidermal growth factor receptor 2-overexpressing locally advanced breast cancers. J Clin Oncol 29: 166 - 173

Di Cosimo S, Baselga J (2008) Targeted therapies in breast cancer: where are we now? Eur J Cancer 44: 2781 - 2790

Diermeier S, Horvath G, Knuechel-Clarke R, Hofstaedter F, Szollosi J, Brockhoff G (2005) Epidermal growth factor receptor coexpression modulates susceptibility to Herceptin in HER2/neu overexpressing breast cancer cells via specific erbB-receptor interaction and activation. Exp Cell Res 304: 604-619

Esteva FJ, Guo H, Zhang S, Santa-Maria C, Stone S, Lanchbury JS, Sahin AA, Hortobagyi GN, Yu D (2011) PTEN, PIK3CA, p-AKT, and p-p70S6K status: association with trastuzumab response and survival in patients with HER2-positive metastatic breast cancer. Am J Pathol 177: 1647-1656

Fessler SP, Wotkowicz MT, Mahanta SK, Bamdad C (2009) MUC1* is a determinant of trastuzumab (Herceptin) resistance in breast cancer cells. Breast Cancer Res Treat 118: 113-124
Harris LN, Liotcheva V, Broadwater G, Ramirez MJ, Maimonis P, Anderson S, Everett T, Harpole D, Moore MB, Berry DA, Rizzeri D, Vredenburgh JJ, Bentley RC (2001) Comparison of methods of measuring HER-2 in metastatic breast cancer patients treated with high-dose chemotherapy. J Clin Oncol 19: 1698-1706

Harris LN, You F, Schnitt SJ, Witkiewicz A, Lu X, Sgroi D, Ryan PD, Come SE, Burstein HJ, Lesnikoski BA, Kamma M, Friedman PN, Gelman R, Iglehart JD, Winer EP (2007) Predictors of resistance to preoperative trastuzumab and vinorelbine for HER2-positive early breast cancer. Clin Cancer Res 13: 1198-1207

Hikita ST, Kosik KS, Clegg DO, Bamdad C (2008) MUC1* mediates the growth of human pluripotent stem cells. PLoS One 3: e3312

Jansen RL, Hupperets PS, Arends JW, Joosten-Achjanie SR, Volovics A, Schouten HC, Hillen HF (1998) MIB-1 labelling index is an independent prognostic marker in primary breast cancer. $\mathrm{Br} J$ Cancer 78: 460-465

Jemal A, Siegel R, Ward E, Hao Y, Xu J, Murray T, Thun MJ (2008) Cancer statistics, 2008. CA Cancer J Clin 58: 71-96

Joensuu H, Kellokumpu-Lehtinen PL, Bono P, Alanko T, Kataja V, Asola R, Utriainen $\mathrm{T}$, Kokko R, Hemminki A, Tarkkanen M, TurpeenniemiHujanen $\mathrm{T}$, Jyrkkio $\mathrm{S}$, Flander $\mathrm{M}$, Helle $\mathrm{L}$, Ingalsuo $\mathrm{S}$, Johansson $\mathrm{K}$, Jaaskelainen AS, Pajunen M, Rauhala M, Kaleva-Kerola J, Salminen T, Leinonen M, Elomaa I, Isola J (2006) Adjuvant docetaxel or vinorelbine with or without trastuzumab for breast cancer. $N$ Engl J Med 354: 809-820

Lane HA, Motoyama AB, Beuvink I, Hynes NE (2001) Modulation of p27/ Cdk2 complex formation through 4D5-mediated inhibition of HER2 receptor signaling. Ann Oncol 12(Suppl 1): S21-S22

Lerma E, Catasus L, Gallardo A, Peiro G, Alonso C, Aranda I, Barnadas A, Prat J (2008) Exon 20 PIK3CA mutations decreases survival in aggressive (HER-2 positive) breast carcinomas. Virchows Arch 453: 133-139

Lu Y, Lin YZ, LaPushin R, Cuevas B, Fang X, Yu SX, Davies MA, Khan H, Furui T, Mao M, Zinner R, Hung MC, Steck P, Siminovitch K, Mills GB (1999) The PTEN/MMAC1/TEP tumour suppressor gene decreases cell growth and induces apoptosis and anoikis in breast cancer cells. Oncogene 18: 7034-7045

Lu Y, Zi X, Pollak M (2004) Molecular mechanisms underlying IGF-Iinduced attenuation of the growth-inhibitory activity of trastuzumab (Herceptin) on SKBR3 breast cancer cells. Int J Cancer 108: 334-341

Lu Y, Zi X, Zhao Y, Mascarenhas D, Pollak M (2001) Insulin-like growth factor-I receptor signaling and resistance to trastuzumab (Herceptin). $J$ Natl Cancer Inst 93: 1852 - 1857 
Mahanta S, Fessler SP, Park J, Bamdad C (2008) A minimal fragment of MUC1 mediates growth of cancer cells. PLoS One 3: e2054

Margariti N, Fox SB, Bottini A, Generali D (2011) "Overcoming breast cancer drug resistance with mTOR inhibitors". Could it be a myth or a real possibility in the short-term future? Breast Cancer Res Treat 128: $599-606$

Morrow PK, Wulf GM, Ensor J, Booser DJ, Moore JA, Flores PR, Xiong Y, Zhang S, Krop IE, Winer EP, Kindelberger DW, Coviello J, Sahin AA, Nunez R, Hortobagyi GN, Yu D, Esteva FJ (2011) Phase I/II study of trastuzumab in combination with everolimus (RAD001) in patients with HER2-overexpressing metastatic breast cancer who progressed on trastuzumab-based therapy. J Clin Oncol 29(23): 3126-3132

Murphy CG, Modi S (2009) HER2 breast cancer therapies: a review. Biologics 3: $289-301$

Nagata Y, Lan KH, Zhou X, Tan M, Esteva FJ, Sahin AA, Klos KS, Li P, Monia BP, Nguyen NT, Hortobagyi GN, Hung MC, Yu D (2004) PTEN activation contributes to tumour inhibition by trastuzumab, and loss of PTEN predicts trastuzumab resistance in patients. Cancer Cell 6: $117-127$

Nagy P, Friedlander E, Tanner M, Kapanen AI, Carraway KL, Isola J, Jovin TM (2005) Decreased accessibility and lack of activation of ErbB2 in JIMT-1, a herceptin-resistant, MUC4-expressing breast cancer cell line. Cancer Res 65: 473-482

Nahta R, O'Regan RM (2011) Evolving strategies for overcoming resistance to HER2-directed therapy: targeting the PI3K/Akt/mTOR pathway. Clin Breast Cancer 10(Suppl 3): S72-S78

Nahta R, Takahashi T, Ueno NT, Hung MC, Esteva FJ (2004) P27(kip1) down-regulation is associated with trastuzumab resistance in breast cancer cells. Cancer Res 64: 3981-3986

Nahta R, Yuan LX, Zhang B, Kobayashi R, Esteva FJ (2005) Insulin-like growth factor-I receptor/human epidermal growth factor receptor 2 heterodimerization contributes to trastuzumab resistance of breast cancer cells. Cancer Res 65: 11118-11128

Nguyen PL, Taghian AG, Katz MS, Niemierko A, Abi Raad RF, Boon WL, Bellon JR, Wong JS, Smith BL, Harris JR (2008) Breast cancer subtype approximated by estrogen receptor, progesterone receptor, and HER-2 is associated with local and distant recurrence after breast-conserving therapy. J Clin Oncol 26: 2373-2378

Panigrahi AR, Pinder SE, Chan SY, Paish EC, Robertson JF, Ellis IO (2004) The role of PTEN and its signalling pathways, including AKT, in breast cancer; an assessment of relationships with other prognostic factors and with outcome. J Pathol 204: 93-100

Pegram MD, Pienkowski T, Northfelt DW, Eiermann W, Patel R, Fumoleau P, Quan E, Crown J, Toppmeyer D, Smylie M, Riva A, Blitz S, Press MF, Reese D, Lindsay MA, Slamon DJ (2004) Results of two open-label, multicenter phase II studies of docetaxel, platinum salts, and trastuzumab in HER2-positive advanced breast cancer. J Natl Cancer Inst 96: 759-769

Peiro G, Adrover E, Sanchez-Tejada L, Lerma E, Planelles M, Sanchez-Paya J, Aranda FI, Giner D, Gutierrez-Avino FJ (2011) Increased insulin-like growth factor-1 receptor mRNA expression predicts poor survival in immunophenotypes of early breast carcinoma. Mod Pathol 24: 201-208

Peiro G, Aranda FI, Adrover E, Niveiro M, Alenda C, Paya A, Segui J (2007) Analysis of HER2 by chromogenic in situ hybridization and immunohistochemistry in lymph node-negative breast carcinoma: prognostic relevance. Hum Pathol 38: 26-34

Peiro G, Benlloch S, Sanchez-Tejada L, Adrover E, Lerma E, Peiro FM, Sanchez-Paya J, Aranda FI (2009) Low activation of insulin-like growth factor 1-receptor (IGF1R) is associated with local recurrence in early breast carcinoma. Breast Cancer Res Treat 117: 433-441

Piccart-Gebhart MJ, Procter M, Leyland-Jones B, Goldhirsch A, Untch M, Smith I, Gianni L, Baselga J, Bell R, Jackisch C, Cameron D, Dowsett M, Barrios CH, Steger G, Huang CS, Andersson M, Inbar M, Lichinitser M, Lang I, Nitz U, Iwata H, Thomssen C, Lohrisch C, Suter TM, Ruschoff J, Suto T, Greatorex V, Ward C, Straehle C, McFadden E, Dolci MS, Gelber RD (2005) Trastuzumab after adjuvant chemotherapy in HER2-positive breast cancer. N Engl J Med 353: 1659-1672
Razis E, Bobos M, Kotoula V, Eleftheraki AG, Kalofonos HP, Pavlakis K, Papakostas P, Aravantinos G, Rigakos G, Efstratiou I, Petraki K, Bafaloukos D, Kostopoulos I, Pectasides D, Kalogeras KT, Skarlos D, Fountzilas G (2011) Evaluation of the association of PIK3CA mutations and PTEN loss with efficacy of trastuzumab therapy in metastatic breast cancer. Breast Cancer Res Treat 128: 447-456

Saal LH, Holm K, Maurer M, Memeo L, Su T, Wang X, Yu JS, Malmstrom PO, Mansukhani M, Enoksson J, Hibshoosh H, Borg A, Parsons R (2005) PIK3CA mutations correlate with hormone receptors, node metastasis, and ERBB2, and are mutually exclusive with PTEN loss in human breast carcinoma. Cancer Res 65: 2554-2559

Samuels Y, Wang Z, Bardelli A, Silliman N, Ptak J, Szabo S, Yan H, Gazdar A, Powell SM, Riggins GJ, Willson JK, Markowitz S, Kinzler KW, Vogelstein B, Velculescu VE (2004) High frequency of mutations of the PIK3CA gene in human cancers. Science 304: 554

Slamon DJ, Clark GM, Wong SG, Levin WJ, Ullrich A, McGuire WL (1987) Human breast cancer: correlation of relapse and survival with amplification of the HER-2/neu oncogene. Science 235: 177-182

Slamon DJ, Godolphin W, Jones LA, Holt JA, Wong SG, Keith DE, Levin WJ, Stuart SG, Udove J, Ullrich A, Press MF (1989) Studies of the HER-2/neu proto-oncogene in human breast and ovarian cancer. Science 244: 707-712

Slamon DJ, Leyland-Jones B, Shak S, Fuchs H, Paton V, Bajamonde A, Fleming T, Eiermann W, Wolter J, Pegram M, Baselga J, Norton L (2001) Use of chemotherapy plus a monoclonal antibody against HER2 for metastatic breast cancer that overexpresses HER2. $N$ Engl J Med 344: $783-792$

Soria JC, Lee HY, Lee JI, Wang L, Issa JP, Kemp BL, Liu DD, Kurie JM, Mao L, Khuri FR (2002) Lack of PTEN expression in non-small cell lung cancer could be related to promoter methylation. Clin Cancer Res 8: 1178-1184

Stemke-Hale K, Gonzalez-Angulo AM, Lluch A, Neve RM, Kuo WL, Davies M, Carey M, Hu Z, Guan Y, Sahin A, Symmans WF, Pusztai L, Nolden LK, Horlings H, Berns K, Hung MC, van de Vijver MJ, Valero V, Gray JW, Bernards R, Mills GB, Hennessy BT (2008) An integrative genomic and proteomic analysis of PIK3CA, PTEN, and AKT mutations in breast cancer. Cancer Res 68: 6084-6091

Untch M, Gelber RD, Jackisch C, Procter M, Baselga J, Bell R, Cameron D, Bari M, Smith I, Leyland-Jones B, de Azambuja E, Wermuth P, Khasanov R, Feng-Yi F, Constantin C, Mayordomo JI, Su CH, Yu SY, Lluch A, Senkus-Konefka E, Price C, Haslbauer F, Suarez Sahui T, Srimuninnimit V, Colleoni M, Coates AS, Piccart-Gebhart MJ, Goldhirsch A (2008) Estimating the magnitude of trastuzumab effects within patient subgroups in the HERA trial. Ann Oncol 19: 1090-1096

Vanhaesebroeck B, Alessi DR (2000) The PI3K-PDK1 connection: more than just a road to PKB. Biochem J 346(Part 3): $561-576$

Viani GA, Afonso SL, Stefano EJ, De Fendi LI, Soares FV (2007) Adjuvant trastuzumab in the treatment of HER-2-positive early breast cancer: a meta-analysis of published randomized trials. BMC Cancer 7: 153

Vogel CL, Cobleigh MA, Tripathy D, Gutheil JC, Harris LN, Fehrenbacher L, Slamon DJ, Murphy M, Novotny WF, Burchmore M, Shak S, Stewart SJ, Press M (2002) Efficacy and safety of trastuzumab as a single agent in first-line treatment of HER2-overexpressing metastatic breast cancer. J Clin Oncol 20: 719-726

Yamashita H, Nishio M, Toyama T, Sugiura H, Zhang Z, Kobayashi S, Iwase $\mathrm{H}$ (2004) Coexistence of HER2 over-expression and p53 protein accumulation is a strong prognostic molecular marker in breast cancer. Breast Cancer Res 6: R24-R30

Yao E, Zhou W, Lee-Hoeflich ST, Truong T, Haverty PM, Eastham-Anderson J, Lewin-Koh N, Gunter B, Belvin M, Murray LJ, Friedman LS, Sliwkowski MX, Hoeflich KP (2009) Suppression of HER2/HER3-mediated growth of breast cancer cells with combinations of GDC-0941 PI3K inhibitor, trastuzumab, and pertuzumab. Clin Cancer Res 15: 4147-4156

Zhang S, Huang WC, Li P, Guo H, Poh SB, Brady SW, Xiong Y, Tseng LM, Li SH, Ding Z, Sahin AA, Esteva FJ, Hortobagyi GN, Yu D (2011) Combating trastuzumab resistance by targeting SRC, a common node downstream of multiple resistance pathways. Nat Med 17: 461-469

This work is published under the standard license to publish agreement. After 12 months the work will become freely available and the license terms will switch to a Creative Commons Attribution-NonCommercial-Share Alike 3.0 Unported License. 